\title{
Do religious differences matter? An analysis in India
}

\author{
Diether Gebert \\ Sogang University Business School, Seoul, Korea \\ Sabine Boerner \\ Department of Politics and Management, University of Konstanz, \\ Konstanz, Germany, and \\ Debrabata Chatterjee \\ Indian Institute of Management, Kozhikode, India
}

\begin{abstract}
Purpose - This paper aims to analyze the relationship between religious differences (i.e. religious diversity and tolerance diversity), on the one hand, and dysfunctional intergroup conflicts, on the other.

Design/methodology/approach - A quantitative research design is used, through which the paper examines 47 public schools in India.

Findings - Religious diversity, that is, the distribution of heterogeneous religious affiliations in an organization, is unrelated to dysfunctional intergroup conflicts. By contrast, tolerance diversity, that is, the heterogeneity of organizational members' beliefs regarding the question of how strictly religious commandments should be followed, is positively related to dysfunctional conflicts.

Research limitations/implications - The results of this study are limited to public organizations in the Indian context.

Practical implications - Since religious diversity is not connected to intergroup conflicts, fostering religious diversity in organizations could render the societal norm "unity in diversity" more authentic and attractive. This in turn would enhance the ability of different religions to cooperate in Indian organizations. In contrast with religious diversity, the heterogeneity of religious tolerance is significantly related to intergroup conflicts; a possible remedy could be the use of a transformational leadership style.

Originality/value - This study is the first to investigate both religious diversity and tolerance diversity in their effects on the emergence of intergroup conflicts, that is, apparent emotional tensions between organizational subgroups.
\end{abstract}

Keywords Religion, Religious fundamentalism, Intergroup relations, India

Paper type Research paper

Owing to actual socio-demographic trends such as rising globalization and internationalization, heterogeneity of organizational workforce is increasing (Jackson et al., 2003). However, diversity, defined as heterogeneity of members regarding, for example, gender, age or ethnicity, is a double-edged sword (Van Knippenberg and

This research was part of a Small Grant Research Project financed by the Indian Institute of Management Kozhikode (IIMK), India. In addition, the authors thank Prof. Krishnan for his advice in the starting phase of the project and Prof. Ramez for his very helpful coordination of the translation of the questionnaire into Malayalam. 
Schippers, 2007). On the one hand, by enhancing the range of perspectives available in the team, diversity can enable processes of information sharing and decision making, thereby enhancing team performance (Van Knippenberg et al., 2004). On the other hand, however, diversity may trigger processes of social categorization, resulting in conflict, which in turn will derogate the performance of the diverse team (Tajfel and Turner, 1986; Jackson et al., 2003; Gebert, 2004). Following the latter line of research, this paper focuses on intergroup conflicts, that is, apparent emotional tensions between subgroups in diverse organizational teams.

In the literature, surface-level diversity (e.g. age, gender) is distinguished from deep-level diversity (e.g. educational diversity) (Harrison et al., 2002). In this paper, we focus on religious diversity, categorized as a form of deep-level diversity. Since globalization, migration, and growing international mobility lead to increasing religious diversity on labor markets, the workforce of many organizations is equally confronted with rising religious diversity (Wuthnow, 2004). Compared to other forms of deep-level diversity, religious diversity seems unique in two respects.

First, religion has a high personal relevance for many believers (Wellman and Tokuno, 2004). By making promises of salvation, religion provides believers with a sense of meaning and guidance that extend beyond his or her secular existence (Wellman and Tokuno, 2004). The existential relevance of religious believes manifests in the willingness of many adherents to sacrifice their lives in the service of their religion. Being confronted with different religions may thus constitute an identity threat for members of an organizational team (Brewer and Brown, 1998). Second, religious precepts, rules, and commandments are universal in that they pertain to all aspects of life. Religious differences therefore go hand in hand with differences in political and cultural goals (Beyer, 2003). Since religion affects nearly all aspects of reality, tensions among persons with different religious belief systems may ensue in many ways. Hence, in contrast to functional or educational diversity, religious diversity does not merely lead to different thought worlds in organizations (Dougherty, 2006), but to different world views.

Owing to the relevance of religiosity, conflicts rising from religiosity are of particular personal importance when manifested in organizations; due to the universality of religiosity, these conflicts are all-embracing with regard to many different aspects of everyday personal life. We therefore assume that religious differences in organizations generally include a high potential for conflicts. In this paper, we investigate how religious diversity is related to intergroup conflicts.

For this investigation, we consider the context of Indian organizations to be particularly promising. From a historical point-of-view, the relationship between Hindus and Muslims is troubled in India. Conflicts between these religious communities have resulted in the division of India in 1947 by founding of the independent Islamic Republic of Pakistan. At present, the relationship between Hindus and Muslims is marked by occasional riots and attacks on places of worship. Likewise, attacks against Christians are documented (Lobo, 2002; Melanchthon, 2002), which could be interpreted as a reaction to Christian attempts to evangelize Hindus. A recent report on a government appointed committee to inquire attacks on churches in a southern Indian state mentions, for example, that "massive conversions to Christianity through circumstances and inducements" might have been a possible reason for these conflicts (The Hindu, 2010). Given this problematic societal context, religious 
differences may fuel the emergence of conflicting subgroups in Indian organizations. While all employees in Indian organizations are members of the Indian society, most of them are also members of particular religious communities. This multiple identity (Tajfel and Turner, 1986) provides the link by which religious tensions on the societal level may transfer into tensions at the organizational level. In principle, this link is likely to exist in other countries as well. However, the Indian context describes above allows to analyze this transfer quasi under a magnifying lens.

In our study, we focus on two facets of religious differences in organizations. First, we analyze religious diversity, that is, the number and distribution of heterogeneous religious affiliations in an organization. In particular, we investigate the distribution of Hindus, Christians, and Muslims in Indian organizations. Second, we consider tolerance diversity, that is, the heterogeneity of organizational members' beliefs regarding the question how strictly religious commandments should be followed. Apart from their respective religious affiliations, organizational members may differ with regard to the question whether religious commandments should be followed literally and uncompromisingly (low tolerance) or less literally, allowing to make compromises (high tolerance) (Hunsberger and Jackson, 2005).

To the best of our knowledge, this study is the first to investigate both types of diversity in their effects on the emergence of intergroup conflicts, that is, apparent emotional tensions between organizational subgroups. In addition, we analyze how eventual intergroup conflicts may derogate organizational performance.

\section{Theory and hypotheses}

Religious diversity and intergroup conficts

Religious diversity, defined as the distribution of Hindus, Christians, and Muslims in Indian organizations, will enhance the emergence of conflicting subgroups along different religious affiliations. Below, we will discuss under which conditions latent intergroup conflicts become manifest in Indian organizations. In a first step, we will outline one argument supporting the notion that religious diversity promotes the emergence of conflicting subgroups; in a second step, we will consider two arguments against the emergence of conflicting subgroups.

Given the diverging political (Lobo, 2002) and cultural preferences (Gorringe, 2005) coming along with diverse religious denominations, religious differences may result in value diversity. As a deep level form of diversity (Harrison et al, 2002), value diversity is only evident if the diverging religious affiliations of organizational members become apparent. In India, however, religious affiliations can easily be concluded from visible features, such as, for example, the Hindu tilaka or team members' first name (Thomas for Christians and Mohammed for Muslims). Therefore, attributions of similar versus dissimilar values are likely, which in turn may result in the categorization of organizational members into in-groups and out-groups (Pelled, 1996; Brewer and Brown, 1998). The attitudes vis-à-vis the respective out-groups are affected, among others, by societal influences (e.g. as communicated by the mass-media) and current political events. Resulting intergroup tensions may, for example, become obvious when organizational members with different religious affiliations apparently avoid each other.

However, arguments against the emergence of intergroup conflicts resulting from religious diversity are also conceivable. First, at the organizational level, the dysfunctional effects of demographic diversity (e.g. gender, race, and nationality) have 
been shown to decline over time (Harrison et al., 2002). Accordingly, with rising organizational tenure, intergroup conflicts emerging from religious diversity may diminish. Further, persistent tensions result in extremely high personal strain for the individual (Lazarus, 1991) in both the private and the professional context. By contrast, harmonious relations can be expected to considerably facilitate organizational coordination and cooperation for everyone involved (Alper et al., 2000). To the degree that individuals anticipate eventual negative consequences of intergroup conflicts, they may tend to avoid them.

Second, particularities of the Indian context have to be considered. During discussions with representatives of Indian organizations when preparing our empirical study, we noticed the norm "unity in diversity" to be of high importance in India. This norm is likely to facilitate informal contacts between different religious groups. For example, Hindus told us that they used to invite their Muslim neighbors for weddings (and vice versa). This practice may reinforce the experience of unity. "Unity in diversity" is also constitutionally enshrined by providing a secular republic in which all religions have equal status. As part of the legal framework, a National Commission of Minorities act was set up under the National Commission of Minorities in 1992 (National Commission for Minorities, 2010). In this act, various policy issues are recommended related to minorities and minorities' rights. Given this political and legal background, the norm of "unity in diversity" may reflect some kind of collective taboo on the subject of religious diversity. For example, in our research project, we were advised not to use the notion of religious diversity, because it is considered to be a highly sensitive topic. Accordingly, we were cautioned about questions related to religious affiliations in our questionnaire. Obviously, research on religious intolerance seems to break a taboo. This taboo may intensify the already given societal disposition of "unity in diversity", resulting in a separation between the private sphere and the more "secular" professional sphere. As a result, the question of religious affiliation may not be considered relevant in the workplace.

In sum, organizational tenure and the norm of "unity in diversity" may reduce out-group categorizations (Brewer, 1999; Hogg and Terry, 2000) along religious diversity in Indian organizations. Instead, members tend to categorize each other as similar in terms of being Indians and in terms of organizational membership, rather than as different in terms of religion (Migdal et al., 1998).

Accordingly, we hypothesize that the described processes on the group, organizational, and societal level will militate against the emergence of manifest intergroup conflicts. As a result, latent intergroup conflicts will not become manifest with higher levels of religious diversity.

H1. In Indian organizations, there will be no positive relationship between religious diversity and intergroup conflicts.

\section{Tolerance diversity and intergroup conflicts}

In contrast, tolerance diversity will facilitate the emergence of intergroup conflicts in Indian organizations. Such conflicts could arise, for example, when organizational members who are not willing to compromise on the question of how strictly religious commandments should be followed face other organizational members who are willing to do so. This constellation is likely to evoke tensions. First, organizational members who expect strict obedience to the commandments of their religion tend to interpret 
their religious beliefs as "ultimate truth". These organizational members may feel the need (if not the obligation) to avow themselves to their religious community, to take a stand according to their religious denomination and - in extreme cases - to assure others of the absolute validity of their own religious convictions (Schaefer, 2008). Unwillingness to compromise is the result of religious dogmatism (Hunsberger and Jackson, 2005), which is closely linked to closed mindedness (Hunsberger and Jackson, 2005). Furthermore, unwillingness to compromise tends to be related to prejudices and authoritarianism (Altemeyer and Hunsberger, 1992; Rowatt et al., 2005; Weaver and Agle, 2002). Arguments made by organizational members with low degrees of religious tolerance may, therefore, induce intergroup conflicts.

Second, organizational members with low religious tolerance also justify strict adherence to their religious norms from a metaphysical standpoint. Hence, they may tend to interpret their loyalty order as an order of intolerance vis-à-vis diverging attitudes or behaviors (Froese et al., 2008). As a consequence, the willingness to compromise and tolerance of diverging attitudes or behaviors appear as some kind of disregard of religious duties. From the perspective of organizational members with low religious tolerance, diverging attitudes, which in the course of debates, are matters that cannot be let rest. Hence, an escalation of tensions is a likely outcome. In contrast to the arguments elaborated for $H 1$, for members with low religious tolerance, the appreciation of harmonious relations may, therefore, not outweigh the (unpleasant) need to tolerate divergent attitudes and behaviors.

Third, at the same time, organizational members with high religious tolerance will not remain idle. In their eyes, their confrontation with low religious tolerance constitutes an identity threat (Brewer and Brown, 1998). This is especially true if their personal willingness to compromise is grounded in the norm for religious tolerance. One possible reaction might be to further increase their willingness to compromise. Conversely, they may also shun members with low levels of tolerance. Thus, differences between organizational members with high versus low degrees of religious tolerance will rather grow than decline. Mutually reinforcing negative attitudes will strengthen the tendency to avoid members of the respective outgroup. In extreme cases, "camps" of low versus high tolerance organizational members will establish (cf. separation; Harrison and Klein, 2007). Thus, we may hypothesize as follows:

H2. In Indian organizations, tolerance diversity is positively related to intergroup conflicts.

\section{Conflicts, mutual assistance, and performance}

The main focus of our study is on the relationship between religious differences and the emergence of intergroup conflicts. However, we additionally analyze:

- the relationship between intergroup conflicts and mutual assistance; and

- the relationship between mutual assistance and performance.

Since relations between conflicts, mutual assistance, and performance have been repeatedly investigated in for-profit organizations (e.g. Jehn et al., 1999), we forgo explicit theoretical reasoning. However, as the relationship between conflicts, mutual assistance, and performance has not been investigated in public organizations - the context of our study - we decided to include it in our study. 
If tensions between subgroups become apparent, the willingness of these subgroups to cooperate with each other will decline (Jehn et al., 1999; Alper et al., 2000). Tensions tend to impair the exchange of ideas (Kane et al., 2005). As a result, mutual assistance of organizational members is inhibited. However, mutual assistance is critical for the generation and implementation of creative solutions (Taggar, 2002; Van der Vegt and Bunderson, 2005). This latter aspect is relevant for our hypothesis, because in our study, the generation of creative solutions (creativity) and the implementation of these solutions (implementation) are relevant outcome criteria for organizational performance.

H3. The more intergroup conflicts rise, the less mutual assistance there will be among members of Indian organizations.

H4. In Indian organizations, higher levels of mutual assistance will be associated with higher levels of creativity $(H 4 a)$ and higher levels of implementation of such creative solutions $(H 4 b)$.

\section{Methods}

Sample and data collection

Since religious differences in organizations have never been analyzed before, we had to decide which type of organization would be most appropriate for our study. Informal investigations prior to our study revealed that religious diversity tends to be high in governmental schools. We therefore decided to focus on governmental schools and contacted the administrative office of the Director of Public Instruction in the state of Kerala, South India. We received a random list of $N=237$ primary and upper primary governmental and governmentally aided schools which cover all regions within Kerala. (Governmentally aided schools are private institutions, which receive financial support by the government.) We confined our sample to these types of schools because only here outside experts (so-called teaching trainers) were available who could provide comparative assessments of the school performance. We decided to include only those schools in the final sample which could be treated as a group -employing between three and 30 teachers besides the headmaster. In each school, all teachers gather weekly in a so-called School Research Group, which tries to develop new pedagogical instruments along the rules released by the regulating authority. These School Research Groups were the subjects of our analyses. The development of new pedagogical instruments aims at moving from a teacher-focussed teaching and learning style to a student-focussed teaching and learning style.

Of the $n=237$ schools and teaching trainers we contacted, 99 schools $(=42$ percent) and 87 teaching trainers $(=37$ percent) were willing to participate in the study. In order to assure the reliability of our study, we decided to include only those schools in which at least 80 percent of the teaching staff returned the completed questionnaire. As a result, our final sample was reduced to $n=47$ schools and $n=47$ teaching trainers. On average, these schools employ 11.7 teachers with 76 percent of them being female; on average, they are 40 years of age and have nine years of school tenure. The majority of the teachers ( 56 percent) are Hindus, followed by Christians (26 percent), Muslims (15 percent), and others (3 percent). 


\section{Measures}

The teachers and teaching trainers of our sample were asked to answer a questionnaire which had been translated from English into Malayalam by using the procedure of back translation (Brislin, 1980). The questionnaire was accompanied by a letter of recommendation by the Director of Public Instruction. With the exception of school performance, all data was collected using this questionnaire.

Religious diversity. We used Blau's (1977) index of heterogeneity to calculate diversity concerning the three major religious affiliations (i.e. Hindus, Christians, Muslim) in our sample. Theoretically, this index can take values from 0 to 1 , with high values indicating that all three religions are equally represented in the School Research Group of a given school.

Tolerance diversity. Following the scale developed by Altemeyer and Hunsberger (1992), we used three items with ordered response categories ("very untrue", "untrue", "in between", "true", and "very true"):

(1) "God has given mankind a complete, unfailing guide to happiness and salvation, which must be totally followed" (reversed polarity);

(2) "The long established traditions in religion show the best way to honor and serve god, and should never be compromised"(reversed polarity); and

(3) "God' s true followers must remember that he requires them to constantly fight Satan and Satan's allies on this earth"(reversed polarity).

Cronbach's alpha for this scale was 0.72 . We run a principal component analysis, revealing one single factor with an eigenvalue above 1 , which explained 64 percent of the variance. In this case, the calculation of $r_{W G(J)}$ and ICCs is not useful. Instead, the heterogeneity of religious tolerance was measured by using the standard deviation following the recommendations by Harrison and Klein (2007).

Intergroup conflicts. Adapting items by Jehn (1995) and Jehn and Mannix (2001), we used a three-item scale to operationalize intergroup conflicts:

(1) "In our School Research Group (SRG), there are subgroups which do not go along with each other";

(2) "In our SRG, there are conflicting relationships between specific subgroups"; and

(3) "Sometimes, emotional tensions between specific subgroups are visible".

Cronbach's alpha was 0.89 . A principal component analysis revealed one single factor with an eigenvalue above 1 , which explained 83 percent of the variance. The coefficient $r_{W G(J)}$ (James et al., 1984) was used to test the admissibility of the aggregation of the individual responses at the SRG level. In combination with the values for the interrater reliability $\left(\mathrm{ICC} 1=0.35\right.$; ICC2 $=0.87$ ), coefficient $r_{W G(J)}$ (meanrwg $=0.91$ ) confirmed the admissibility of the aggregation (Bliese, 2000).

Mutual assistance. To measure the level of mutual assistance, we used a three-items scale:

(1) "Members of this SRG provide and share resources to help each other in the application of new ideas"; 
(2) "Members of this SRG mutually provide practical support for new ideas and their realization"; and

(3) "Members of this SRG help each other in developing new teaching and learning materials".

Cronbach's alpha was 0.77. A principal component analysis revealed one single factor with an eigenvalue above 1 , which explained 69 percent of the variance. The coefficient $r_{W G(D)}$ (James et al., 1984) was used to test the admissibility of the aggregation of the individual responses at the SRG level. In combination with the values for the interrater reliability $(\mathrm{ICC} 1=0.25 ; \mathrm{ICC} 2=0.80)$, coefficient $r_{W G(J)}($ meanrwg $=0.95)$ confirmed the admissibility of the aggregation (Bliese, 2000).

Performance. School performance was assessed by an external expert (teaching trainer) inspecting each school about 5.4 times a year on average. We distinguished two performance criteria, that is, the creativity and the degree of implementation of the newly developed teaching and learning materials. The creativity of the newly developed teaching and learning materials was measured by three items:

(1) "Compared with other schools, this school is more creative in developing new teaching and learning materials";

(2) "Compared with other schools, in the last two years this school changed fundamentally"; and

(3) "Compared with other schools, this school improved only a little bit in making the students think independently" (polarity reversed).

Cronbach's alpha for this scale was 0.80 . A principal component analysis revealed one single factor with an eigenvalue above 1 , which explained 72 percent of the variance The degree of implementation of the newly developed teaching and learning materials was measured with the following three items:

(1) "Compared with other schools, less teachers use the available teaching materials" (polarity reversed);

(2) Compared with other schools, less students use the available learning materials" (polarity reversed); and

(3) "Compared with other schools, less teachers actually encourage self-driven learning among students" (polarity reversed).

Cronbach's alpha was 0.78 . A principal component analysis revealed one single factor with an eigenvalue above 1, which explained 69 percent of the variance.

Control variables. We included a set of control variables which have been confirmed to affect both the emergence of conflicts and organizational performance. This is valid for school size (measured by the number of SRG members), which is likely to be negatively related to group cohesiveness and communication (e.g. Bantel and Jackson, 1989). Following research on demographic diversity (Pelled, 1996; Jackson et al., 2003; Joshi and Roh, 2009), we controlled for age diversity, gender diversity, and school tenure diversity. All three forms of diversity have empirically shown to foster organizational conflicts on the one hand (Milliken and Martins, 1996) and positive synergy on the other hand (cp. Van Knippenberg et al., 2004). Following Harrison and Klein (2007), age diversity and school tenure diversity were measured by using the 
standard deviation. In contrast, gender diversity was measured by the Blau (1977) index. Since tolerance diversity was measured by the standard deviation (cp. Harrison and Klein, 2007), the mean of this variable was additionally included as control.

\section{Results}

We conducted a confirmatory factor analysis (CFA) to examine the discriminant validity of the scales for tolerance diversity, intergroup conflicts, and mutual assistance. As expected, a three-factor model fit the data well $\left(\chi^{2}\right.$ value $=40.14$; $\mathrm{df}=24 ; \mathrm{CFI}=0.99 ; \mathrm{TLI}=0.99 ; \mathrm{RMSEA}=0.07$ ). Table I presents the means, standard deviations, and correlations among the study variables.

Only tolerance diversity is correlated significantly positively $(r=0.37 ; p<0.05)$ with intergroup conflicts. Higher intergroup conflicts are associated with less mutual assistance $(r=-0.59, p<0.01)$, while mutual assistance is positively related with both creativity $(r=0.38 ; p<0.05)$ and implementation $(r=0.35 ; p<0.05)$ in the SRGs under study. To test our hypotheses, we ran hierarchical regression analyses (see Table II).

In Model 1, intergroup conflict was regressed on the controls, religious diversity, and tolerance diversity. Analyzing the control variables, only school size significantly predicted intergroup conflict $(\beta=0.30, p<0.10$, see Model 1a, Step 1; $\beta=0.34$, $p<0.05$, see Model 1b, Step 1), indicating that intergroup conflicts are more likely to emerge in schools of larger size. In Model 1-a, $H 1$ was tested. Step 2 reveals that religious diversity does not significantly contribute to intergroup conflicts $(\beta=0.17$, n.s.). H1, predicting no positive relationship between religious diversity and intergroup conflicts, was thus confirmed. In Model 1-b, $H 2$ was tested. Interpreting the data provided in Step 2, tolerance diversity contributes significantly to explain intergroup conflicts $(B=0.33 ; p<0.05)$. Overall, Model 1-b (Step 2) explains 30 percent of the variance in intergroup conflicts $\left(\Delta \mathrm{d} R^{2}=9\right.$ percent; $\left.F=5.19 ; p<0.05\right)$. Therefore, $H 2$, predicting a positive relationship between tolerance diversity and intergroup conflicts, was equally confirmed.

H3 predicted a negative relationship between intergroup conflicts and mutual assistance in the team. This hypothesis was tested in Model 2 by regressing mutual assistance on the controls and intergroup conflicts. As shown in Step 1, school size is again the only significant control variable: The larger the school, the less likely is mutual assistance among teachers $(B=-0.31, p<0.10)$. Step 2 reveals a significantly negative relationship between intergroup conflicts and mutual assistance $(B=-0.53$; $p<0.001)$. By adding conflicts as a predictor to the regression equation, the explained variance in mutual assistance rises from $R^{2}=0.14$ to $R^{2}=0.37\left(\Delta \mathrm{d} R^{2}=23\right.$ percent; $F=15.23 ; p<0.001) . H 3$ was thus confirmed.

Finally, $H 4$ was tested in Model $3(H 4 a)$ and Model $4(H 4 b)$. Regarding creativity, two of the control variables turned out to be significant (see Step 1): Whereas gender diversity is a negative predictor of creativity $(\beta=-0.33, p<0.05)$, tenure diversity is a positive predictor of creativity $(B=0.26 ; p<0.10)$. As was hypothesized, mutual assistance is a positive predictor of creativity (see Step $2 ; \beta=0.41, p<0.01$ ). Including mutual assistance in the regression equation, 33 percent of the variance in creativity could be explained ( $\Delta \mathrm{d} R^{2}=15$ percent, $F=9.00 ; p<0.01$ ). $H 4 a$, predicting a positive relationship between mutual assistance and creativity, was thus confirmed. Similarly, $H 4 b$ was confirmed, predicting a positive relationship between mutual assistance and 


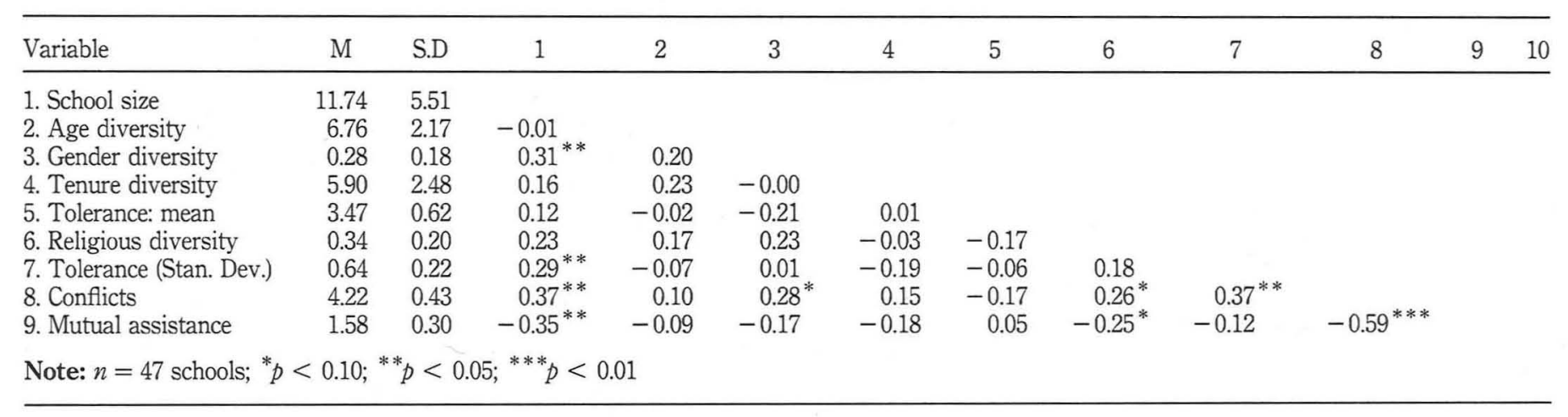






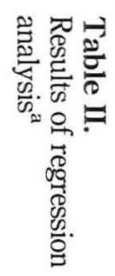

હ

\begin{tabular}{|c|c|c|c|c|c|c|c|c|c|c|}
\hline \multirow[b]{2}{*}{ Independent variables } & \multicolumn{2}{|c|}{$\begin{array}{l}\text { Model 1 - a. } \\
\text { Conflict }\end{array}$} & \multicolumn{2}{|c|}{$\begin{array}{l}\text { Model } 1-b \text {. } \\
\text { Conflict }\end{array}$} & \multicolumn{2}{|c|}{$\begin{array}{l}\text { Model 2. Mutual } \\
\text { Assistance }\end{array}$} & \multicolumn{2}{|c|}{$\begin{array}{l}\text { Model 3. Performance: } \\
\text { Creativity }\end{array}$} & \multicolumn{2}{|c|}{$\begin{array}{c}\text { Model } 4 . \\
\text { Performance: } \\
\text { Implementation }\end{array}$} \\
\hline & Step 1. & Step 2. & Step 1. & Step 2. & Step 1. & Step 2. & Step 1. & & Step 1. & Step 2. \\
\hline \multirow{9}{*}{$\begin{array}{l}\text { Step 1: Controls } \\
\text { School size } \\
\text { Age diversity } \\
\text { Gender diversity } \\
\text { Tenure diversity } \\
\text { Tolerance: mean } \\
\text { Step 2: Main effects } \\
\text { Religious diversity } \\
\text { Tolerance diversity } \\
\text { Conflicts } \\
\text { Mutual assistance } \\
R^{2} \\
\Delta R^{2}\end{array}$} & & & & & & & & & & \\
\hline & $\begin{array}{l}0.30^{*} \\
0.47\end{array}$ & $\begin{array}{l}0.27^{*} \\
0.2\end{array}$ & $0.34^{* *}$ & 0.21 & $\begin{array}{l}-0.31^{* *} \\
-0.05\end{array}$ & $\begin{array}{l}-0.15 \\
-0.03\end{array}$ & $\begin{array}{r}-0.04 \\
0.02\end{array}$ & 0.09 & 0.13 & $0.28^{*}$ \\
\hline & 0.18 & 0.15 & 0.12 & 0.17 & -0.06 & 0.03 & $-0.33^{* *}$ & $-0.30 * *$ & -0.23 & $\begin{array}{l}-0.20 \\
-0\end{array}$ \\
\hline & 0.09 & 0.10 & 0.09 & 0.17 & -0.11 & -0.06 & $0.26^{*}$ & $0.31^{* *}$ & 0.24 & $0.29^{* *}$ \\
\hline & & & & & & & & & & \\
\hline & & 0.17 & & & & & & & & \\
\hline & & & & $0.33^{* *}$ & & $-0.53^{* * *}$ & & & & \\
\hline & & & & & & & & $0.41^{* * *}$ & & $\begin{array}{l}0.47^{* * *} \\
34\end{array}$ \\
\hline & $\begin{array}{l}18 \\
18\end{array}$ & $\begin{array}{r}2.5 \\
2.5\end{array}$ & $\begin{array}{l}21 \\
21\end{array}$ & $\begin{array}{l}30 \\
9^{* *}\end{array}$ & $\begin{array}{l}14 \\
14\end{array}$ & $23^{* * *}$ & $\begin{array}{l}18 \\
18\end{array}$ & $\begin{array}{l}33 \\
15^{* * *}\end{array}$ & $\begin{array}{l}15 \\
15\end{array}$ & $\begin{array}{l}34 \\
19^{* * *}\end{array}$ \\
\hline Note: $n=47$ Schoo & tandar & regr & coeffic & e repc & ${ }^{*} p<0$ & ${ }^{*} p<0$ & ${ }^{*} p<0$ & & & \\
\hline
\end{tabular}


the implementation of creative solutions. In Step 2 (Model 4), two of the control variables were significant. The implementation of creative solutions is more likely the larger the school $(\beta=0.28, p<0.10)$ and the higher the level of tenure diversity in the team $(\beta=0.29, p<0.05)$. Moreover, mutual assistance significantly predicted the implementation of creative solutions $\left(B=0.47 p<0.01 ; \Delta \mathrm{d} R^{2}=19\right.$ percent; $F=11.98 ; p<0.001)$.

\section{Discussion}

In India, like in many other countries, relations between different religious communities have proved to cause dysfunctional conflicts at the societal level. Against this background, the paper investigates the question whether religious differences may also result in conflicts at an organizational level. According to the results of our study of $n=47$ public schools, it is not religious diversity, but diversity of religious tolerance (or rather intolerance) which is significantly related to the emergence of intergroup conflicts. Moreover, our data reveal that intergroup conflicts impede mutual assistance in the School Research Groups under study. At the same time, mutual assistance is a predictor of school performance, measured as both the creativity and the implementation of the newly developed teaching and learning materials. Thus, diversity of religious tolerance indirectly affects school performance.

The non-significant relation between religious diversity and intergroup conflicts can, at least in part, be explained by the fact that most of the teachers have known each other for a long time (cp. Harrison et al., 2002). In our sample, mean school tenure was nine years. In addition, the non-significant relation can be explained by particularities of the Indian context, where the norm "unity in diversity" might prevent latent intergroup conflicts from becoming manifest.

For organizational members with low religious tolerance, however, things appear to be different. In our sample, 41 percent of the teachers reached a value of 4 or more on the five point scale for tolerance. (Since the polarity of this scale was reversed, these teachers are thus characterized by low religious tolerance.) Following self-categorization theory (Oakes et al., 1991), competing religious affiliations seem to have such a high salience that inclusive categorizations (Brewer, 1999) of members belonging to other religious groups become extremely difficult. Obviously, the mechanisms that avoid the emergence of intergroup conflicts are not working in this part of our sample. Quite the contrary, teachers with a low religious tolerance rather seem to enhance separation. As a result, so-called camps of low versus high tolerance organizational members tend to get established.

\section{Managerial implications}

Provided that our finding that religious diversity is not significantly related to intergroup conflicts will be confirmed by further research, several practical implications can be formulated. While many people in India, like in other countries (Wuthnow, 2007; Wiersema and Bird, 1993) may consider religious diversity to be primarily dangerous, our results suggests a different picture. Since religious diversity is not connected to intergroup conflicts, fostering religious diversity in organizations could render the societal norm "unity in diversity " more authentic and attractive. This in turn would enhance the ability of different religions to cooperate in Indian organizations. 
In contrast with religious diversity, the heterogeneity of religious tolerance is significantly related to intergroup conflicts, which in turn impede mutual assistance of organizational members. A possible remedy could be the use of a transformational leadership style. Since it has proved to exert integrating effects in other organizational contexts (Bass et al., 2003), it may also contribute to reduce the danger of subgroup formation among organizational members with heterogeneous levels of religious tolerance (Huttermann and Boerner, in press; Kearney and Gebert, 2009). However, since organizational members who tend to literally interpret religious commandments are likely to be more closed-minded (Kruglanski and Webster, 1996; Hunsberger and Jackson, 2005), this option can be doubted.

\section{Limitations and further research}

The results of our study are limited to public organizations. We assume that public schools differ from business organizations in the first place in the degree of status differentiation. Compared to public schools, hierarchy tends to be more pronounced in business organizations. If status diversity is perceived at least partially as a function of religious diversity, this problem will be more obvious in business companies than in schools. The more religious minorities tend to interpret such status differences (cp. Davidson, 2008) as some kind of discrimination, the higher the risk of identity threats (Tajfel and Turner, 1986) that may result in resource conflicts (concerning, for example, attractive jobs). If the results of our study could be replicated in other context, two main conclusions could be drawn for research on diversity in organizational teams.

First, although competing theoretical expectations exist, the extant research is not very optimistic about the effects of diversity on team performance. Most comprehensive reviews draw ambivalent conclusions on the effects of diversity on various indicators of team performance (Harrison and Klein, 2007; Jackson et al., 2003). The main argument for the negative impact of diversity on performance is that diversity may enhance dysfunctional conflicts. In contrast, our study reveals that religious diversity, although a highly relevant and universal form of diversity, is not related to intergroup conflict. As discussed above, this result may be due to the particular context of our investigation. Since by far the most research on diversity is conducted in Western context, our results emphasize that more intercultural research on the effects of diversity is necessary.

In particular, further research on religious differences, i.e. religious diversity and tolerance diversity in different parts of the world is needed. If, for example, in the US or in Europe conflicting religious subgroups emerge at the societal level, this danger is met by a strategy of conflict avoidance (Schaefer, 2008). Thus, the management of religious differences is limited to the strategy of temporal or spatial segregation (cp. Wuthnow, 2007). To the degree that similar tendencies toward segregation can equally be found at the organizational level, the possible benefits of religious differences - for example, the demonstration of taking the tolerance norm seriously - are systematically obstructed. Moreover, due to the results of our study, segregation does not seem to be necessary. The widespread fear of the negative effects of religious diversity could thus reveal to be unfounded. Further research will have to discover if this result can be generalized to other contexts. We therefore consider the systematic analysis of conditions under which religious diversity will not induce conflicts to be a major question for future research. This seems to be all the more true since the strategy of 
spatial and temporal segregation used all over the world is an unsatisfying approach to manage religious diversity (Wuthnow, 2007) - at least from a normative perspective. Therefore, other countries, such as the US or Europe, can learn, that problems do not necessarily rise from religious diversity as such; rather, the central issue seems to be the handling of religious intolerance.

Second, we were the first to introduce the dimension of tolerance diversity, defined as the heterogeneity of organizational members' beliefs regarding the question how strictly religious commandments should be followed. As was hypothesized, tolerance diversity is positively related to dysfunctional conflicts. This result could contribute to the extant literature on diversity in that in helps to differentiate the construct of team diversity. To date, diversity research is focused on different forms of surface-level diversity (e.g. age, gender) and deep-level diversity (e.g. educational diversity). However, members' tolerance for diversity has hardly been accounted for in the literature. Put it differently, the rigidity with which team members insist on their respective diverse values or beliefs has never been analyzed. So far, only related constructs such as diversity believes or diversity management competences have been included, albeit as moderators of the relationship between diversity and performance. Pointing to the different effects of religious diversity and tolerance diversity, our study could thus stimulate the differentiation of the construct team diversity in further research.

\section{References}

Alper, S., Tjosvold, D. and Law, K.S. (2000), "Conflict management, efficacy and performance in organizational teams”, Personnel Psychology, Vol. 53 No. 3, pp. 625-42.

Altemeyer, B. and Hunsberger, B. (1992), “Authoritarianism, religious fundamentalism, quest, and prejudice", The International Journal for Philosophy of Religion, Vol. 2 No. 2, pp. 113-33.

Bantel, K. and Jackson, S.E. (1989), "Top management and innovations in banking: does the composition of the top team make a difference?", Strategic Management Journal, Vol. 10, Supplement 1, pp. 107-24.

Bass, B.M., Avolio, B.J., Jung, D.I. and Berson, Y. (2003), "Predicting unit performance by assessing transformational and transactional leadership", Journal of Applied Psychology, Vol. 88 No. 2, pp. 207-18.

Beyer, P. (2003), "Constitutional privilege and constituting pluralism: religious freedom in a national, global, and legal context", Journal for the Scientific Study of Religion, Vol. 42 No. 3, pp. 333-9.

Blau, P.M. (1977), Inequality and Heterogeneity, Free Press, New York, NY.

Bliese, P.D. (2000), "Within-group agreement, non-independence, and reliability: implications for data aggregation and analysis", in Kozlowski, S.W.J. and Klein, K.J. (Eds), Multilevel Theory, Research, and Methods in Organizations: Foundations, Extensions, and New Directions, Jossey-Bass/Pfeiffer, San Francisco, CA, pp. 349-82.

Brewer, M.B. (1999), “The psychology of prejudice: ingroup love or outgroup hate?", Journal of Social Issues, Vol. 55 No. 3, pp. 429-44.

Brewer, M.B. and Brown, R.J. (1998), "Intergroup relations", in Gilbert, D.T., Fiske, S.T. and Lindzey, G. (Eds), Handbook of Social Psychology, Vol. 2, McGraw-Hill, Boston, MA, pp. 554-94. 
Brislin, R.W. (1980), "Translation and content analysis of oral and written material", in Triandis, H.C. and Berry, J.W. (Eds), Handbook of Cross-Cultural Psychology, Vol. 2, Allyn \& Bacon, Boston, MA, pp. 349-444.

Davidson, J.D. (2008), "Religious stratification: origins, persistence, and consequences", Sociology of Religion, Vol. 69 No. 2, pp. 371-95.

Dougherty, D. (2006), "Organizing for innovation in the 21st century", in Clegg, S.R., Hardy, C., Lawrence, T.B. and Nord, W.R. (Eds), The Sage Handbook of Organization Studies, Sage Publications, London, pp. 598-617.

Froese, P., Bader, C. and Smith, B. (2008), "Political tolerance and God's wrath in the United States", Sociology of Religion, Vol. 69 No. 1, pp. 29-44.

Gebert, D. (2004), "Durch diversity zu mehr Teaminnovativität? Ein vorläufiges Resümee der empirischen Forschung sowie Konsequenzen für das diversity management", Die Betriebswirtschaft, Vol. 64 No. 4, pp. 412-30.

Gorringe, H. (2005), Untouchable Citizens: Dalit Movements and Democratization in Tamil Nadu, Sage, New Delhi.

Harrison, D.A. and Klein, K.J. (2007), "What's the difference? Diversity constructs and separation, variety, or disparity in organizations", Academy of Management Review, Vol. 32 No. 4, pp. 1199-228.

Harrison, D.A., Prke, K.H., Gavin, J.H. and Florey, A.T. (2002), "Time, teams, and task performance: changing, effects of surface- and deep-level diversity on group functioning", Academy of Management Journal, Vol. 45 No. 5, pp. 1029-45.

(The) Hindu (2010), "Christian church attack: interim report submitted", online edition, available at: www.thehindu.com/2010/02/02/stories/2010020254670700.htm (accessed 20 February 2010).

Hogg, M.A. and Terry, D.J. (2000), "Social identity and self-categorization processes in organizational contexts", Academy of Management Review, Vol. 25 No. 1, pp. 121-40.

Hunsberger, B. and Jackson, L.M. (2005), "Religion, meaning, and prejudice", Journal of Social Issues, Vol. 61 No. 4, pp. 807-26.

Huttermann, H. and Boerner, S. (in press), "Fostering innovation in functionally diverse teams: the two faces of transformational leadership", European Journal of Work and Organizational Psychology.

Jackson, S.E., Joshi, A. and Erhardt, N.L. (2003), "Recent research on team and organizational diversity: SWOT analysis and implications", Journal of Management, Vol. 29 No. 6, pp. 801-30.

James, L.R., Demaree, R.G. and Wolf, G. (1984), "Estimating within-group interrater reliability with and without response bias", Journal of Applied Psychology, Vol. 69 No. 1, pp. 85-98.

Jehn, K.A. (1995), "A multimethod examination of the benefit and detriments of intragroup conflict", Administrative Science Quarterly, Vol. 40 No. 2, pp. 256-82.

Jehn, K.A. and Mannix, E.A. (2001), "The dynamic nature of conflict: a longitudinal study of intragroup conflict and group performance", Academy of Management Journal, Vol. 44 No. 2, pp. 238-51.

Jehn, K.E., Northcraft, G.B. and Neale, M.A. (1999), "Why differences make a difference: a field study of diversity, conflict, and performance in workgroups", Administrative Science Quarterly, Vol. 44 No. 4, pp. 741-63.

Joshi, A. and Roh, H. (2009), "The role of context in work team diversity research: a meta-analytic review", Academy of Management Journal, Vol. 52 No. 3, pp. 599-627. 
Kane, A., Argote, L. and Levine, J.M. (2005), "Knowledge transfer between groups via personnel rotation: effects of social identity and knowledge quality", Organizational Behavior and Human Decision Processes, Vol. 96 No. 1, pp. 56-71.

Kearney, E. and Gebert, D. (2009), "Managing diversity and enhancing team performance: the promise of transformational leadership", Journal of Applied Psychology, Vol. 94 No. 1, pp. 77-89.

Kruglanski, A.W. and Webster, D.M. (1996), "Motivated closing of the mind: seizing and freezing", Psychological Review, Vol. 103 No. 2, pp. 263-83.

Lazarus, R.S. (1991), Emotion and Adaptation, Oxford University Press, New York, NY.

Lobo, L. (2002), "Persecution of Indian Christians", Dialog: A Journal of Theology, Vol. 41 No. 2, pp. 114-22.

Melanchthon, M. (2002), "Persecution of Indian Christians”, Dialog: A Journal of Theology, Vol. 41 No. 2, pp. 103-13.

Migdal, M.J., Hewstone, M. and Mullen, B. (1998), "The effects of crossed categorization on intergroup evaluations: a meta-analysis", British Journal of Social Psychology, Vol. 37 No. 3 , pp. 303-24.

Milliken, FJ. and Martins, L.L. (1996), "Searching for common threads: understanding the multiple effects of diversity in organizational groups", Academy of Management Review, Vol. 21 No. 2, pp. 402-33.

National Commission for Minorities (2010), available at: http://ncm.nic.in/genesis.html (accessed 20 February 2010).

Oakes, P.J., Turner, J.C. and Haslam, S.A. (1991), "Perceiving people as group members: the role of fit in the salience of social categorizations", British Journal of Social Psychology, Vol. 30, pp. 125-44.

Pelled, L.H. (1996), "Demographic diversity, conflict, and work group outcomes: an intervening process theory", Organization Science, Vol. 7 No. 6, pp. 615-31.

Rowatt, W.C., Franklin, L.M. and Cotton, M. (2005), "Patterns and personality correlates of implicit and explicit attitudes towards Christians and Muslims", Journal for the Scientific Study of Religion, Vol. 44 No. 1, pp. 29-43.

Schaefer, H.W. (2008), Kampf der Fundamentalismen: Radikales Christentum, Radikaler Islam und Europas Moderne, Insel Verlag, Frankfurt.

Taggar, S. (2002), "Individual creativity and group ability to utilize individual creative resources: a multilevel model", Academy of Management Journal, Vol. 45 No. 2, pp. 315-30.

Tajfel, H. and Turner, J.C. (1986), "The social identity theory of intergroup behavior", in Worchel, S. and Austin, W.G. (Eds), Organization Science, Nelson-Hall, Chicago, IL, pp. 7-24.

Van der Vegt, G.S. and Bunderson, J.S. (2005), "Learning and performance in multi-disciplinary teams: the importance of collective team identification", Academy of Management Journal, Vol. 48 No. 3, pp. 532-47.

Van Knippenberg, D. and Schippers, M.C. (2007), "Work group diversity", Annual Review of Psychology, Vol. 58 No. 1, pp. 515-41.

Van Knippenberg, D., De Dreu, K.W.D. and Homan, A.C. (2004), "Work group diversity and group performance: an integrative model and research agenda", Journal of Applied Psychology, Vol. 89 No. 5, pp. 1008-22.

Weaver, G.R. and Agle, B. (2002), "Religiosity and ethical behaviour in organizations: a symbolic interactionist perspective", Academy of Management Review, Vol. 27 No. 1, pp. 77-97. 
Wellman, J.K. and Tokuno, K. (2004), "Is religious violence inevitable?", Journal for the Scientific Study of Religion, Vol. 43 No. 3, pp. 291-6.

Wiersema, M.F. and Bird, A. (1993), "Organizational demography in Japanese firms: group heterogeneity, individual dissimilarity, and top management team turnover", Academy of Management Journal, Vol. 36 No. 5, pp. 996-1025.

Wuthnow, R. (2004), "Presidential address 2003: the challenge of diversity", Journal for the Scientific Study of Religion, Vol. 43 No. 2, pp. 159-70.

Wuthnow, R. (2007), America and the Challenges of Religious Diversity, Princeton University Press, Princeton, NJ.

\title{
Further reading
}

Silberman, I. (2005), "Religion as a meaning system: implications for the new millennium", Journal of Social Issues, Vol. 61 No. 4, pp. 641-63.

\begin{abstract}
About the authors
Diether Gebert received his $\mathrm{PhD}$ from Munich University. His research interests are in innovation, diversity, and human resource management. He has published several books and articles in international journals.

Sabine Boerner received her $\mathrm{PhD}$ from Berlin Technical University. Her research interests are in leadership, diversity, and the management of cultural industries. She has published several books and articles in international journals. Sabine Boerner is the corresponding author and can be contacted at: Sabine.boerner@uni-konstanz.de

Debrabata Chatterjee received his $\mathrm{PhD}$ from Indian Institute of Management Kozhikode (IIMK). His research interests include diversity and human resource management.
\end{abstract}

